\title{
PROPERTIES OF DIGESTIVE ENZYMES FROM VISCERAL ORGANS OF TRA (PANGASIUS) CATFISH
}

\author{
Vuong Bao Thy ${ }^{(1)}$, Tran Bich Lam ${ }^{(2)}$, Luu Duan ${ }^{(3)}$ \\ (1) Cuu Long University \\ (2) University of Technology, VNU-HCM \\ (3) Saigon Technology University \\ (Manuscript Received on May $13^{\text {rd }}$ 2010, Manuscript Revised October 14 ${ }^{\text {rd }}$ 2011)
}

\begin{abstract}
In fish processing, viscera are generally considered waste products and often discarded. Our research objective is to use Tra (pangasius) catfish viscera which accounts for 5-6\% of body weight as a source of digestive enzymes. This paper investigated the influence of individual visceral organs of Tra catfish on the activities and properties of lipase, protease and amylase. Results revealed that the hepatopancreas was the best source for three digestive enzymes, with the highest

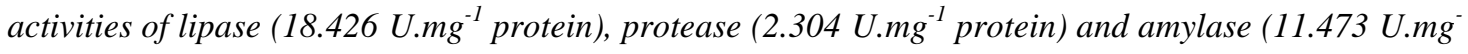
${ }^{1}$ protein), in comparison with intestine or mixed viscera. The optimal pH of Lipases from the hepatopancreas, intestine and mixed viscera were of 8, 7.5 and 8 respectively, of Proteases were of 8.5, 9.5, 9, and of Amylases were of 7.5, 8 and 8, respectively. The maximum activities of lipase, protease, and amylase were found at the temperature of 50,55 and $40^{\circ} \mathrm{C}$, respectively.
\end{abstract}

Keywords: digestive enzymes, viscera, lipase, protease, amylase.

\section{INTRODUCTION}

Enzymes from cold-adapted fish species often have higher catalytic activities at low temperatures than their counterparts from warm-blooded animals. High activity of enzymes at low temperatures may be of interest for several industrial applications of enzymes, such as in certain food processing operations that require low processing temperatures. Furthermore, the relatively low thermal stability, often observed in fish enzymes, may also be beneficial in such applications as the enzymes can be inactivated more readily, with less heat treatment, when desired in a given process.

In Tra (pangasius) catfish industry, 30\% are fillets, the rest are by-product and waste, in which, fish viscera, accounting for $5-6 \%$ of total mass, has wide biotechnological potential as a source of digestive enzymes. Hence, the objective of this study was to study on the extraction and characterization of digestive enzyme from Tra (pangasius) catfish viscera.

\section{MATERIALS AND METHODS}

\subsection{Source of enzymes}

Tra (Pangasius) catfish viscera were kindly provided by the fish processing factory 
in Mekong Delta region, VietNam.

Hepatopancreas, intestine or mixed viscera were selected as sources of enzymes.

\subsection{Determination of enzyme activities}

Protease activity was measured using the casein hydrolysis method of Anson modified by Sarath et al (1989).

Lipase activity was determined by measuring fatty acids released from enzymatic hydrolysis of triglycerides in a stabilized emulsion of olive oil (Borlongan 1990).

Amylase activity was measured by the starch hydrolysis method of Wohlgemuth (1931).

Protein content was measured by the method of Lowry et al. (1951), using albumin as the standard.

\subsection{Effect of viscera organ and buffer $\mathrm{pH}$ on} the enzyme activities

Mixed viscera and the intestine and hepatopancreas of the Tra catfish were washed with distilled water and weighed for calculation of the percentage of each organ. Cold $50 \mathrm{mM}$ buffer solution of $\mathrm{pH}$ 6-11 was added in the 1:2 $(w / v)$ ratios of viscera to buffer. The mixture was homogenized for 1-2 min and stirred in 30 min at $5^{\circ} \mathrm{C}$ with an electric paddle before filtration through cheese cloth to remove solid residues. The fine particles left in the filtrate were removed by centrifugation at 4,000 rpm for $15 \mathrm{~min}$ at $4^{0} \mathrm{C}$. The supernatant (crude extract) was studied for the effect of $\mathrm{pH}(\mathrm{pH}$ 6.0-11.0, prepared as above) and incubation temperature $\left(35-70^{\circ} \mathrm{C}\right)$ on enzyme activities.
The activities were reported as relative activities compared with the initial enzyme activities.

\subsection{Statistical Analyses}

The statistical analysis of the effect of $\mathrm{pH}$ and temperature on activity was evaluated by analysis of variance (ANOVA) and comparisons between means were performed with Duncan's Multiple Range test. Differences between means were reported as significant if $\mathrm{p}<0.05$. Results are expressed as mean \pm SD for the three experiments. All the statistical analyses were performed using Statgraphic Plus 4.0.

\section{RESULTS AND DISCUSSION}

The average (from 20 fish samples) body weight of Tra Catfish was $1.20 \mathrm{~kg}$ with the viscera yields of $5.8 \%$. This yield was higher than that of skipjack tuna being $5.44 \%$ (Prasertsan et al., 1988)

\subsection{Effect of extraction pH on the enzyme} activities

Viscera organ and the $\mathrm{pH}$ of buffer used in enzyme extraction had a substantial influence on the lipase activity (Figure 1), protease activity (Figure 2) and amylase activity (Figure 3). Both lipase and protease and amylase activities from all sources were highest at $\mathrm{pH} 8$. 


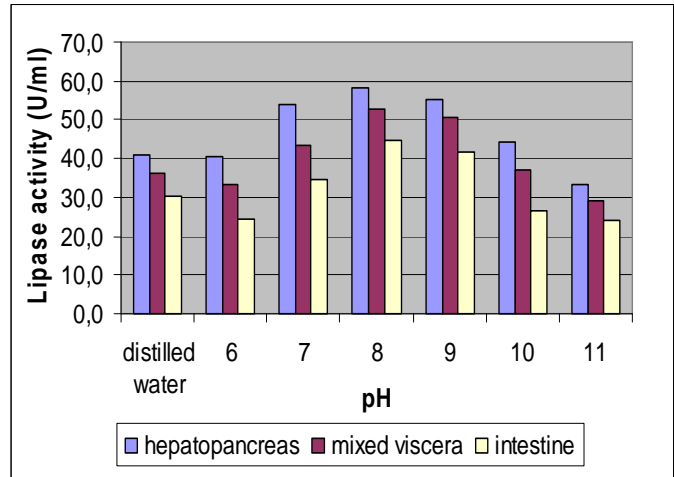

Fig 1. Effect of extraction's pH on lipase activity

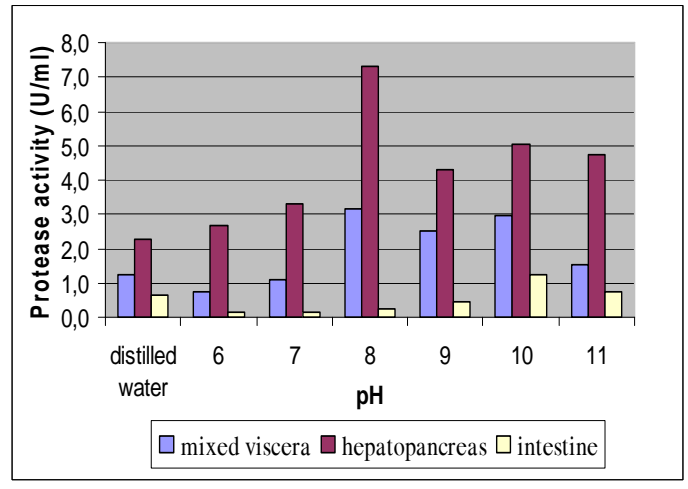

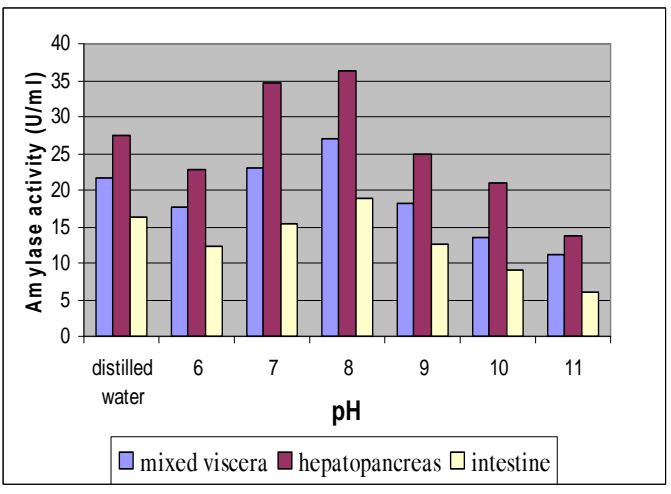

Fig 3. Effect of extraction's pH on amylase activity

Among the individual viscera organs, hepatopancreas gave the highest lipase, protease and amylase activities (Table 1).

Fig 2. :Effect of extraction's pH on protease activity

Table 1. Enzyme activities

\begin{tabular}{|c|c|c|c|}
\hline \multirow[t]{2}{*}{ Visceral organs } & \multirow{2}{*}{$\begin{array}{l}\text { Optimum } \mathrm{pH} \text { for } \\
\text { extraction }\end{array}$} & \multicolumn{2}{|c|}{ Lipase } \\
\hline & & Activity $(\mathrm{U} / \mathrm{ml})$ & Specific Activity (U/mg) \\
\hline Mixed viscera & 8 & $52,74 \pm 1,85^{b}$ & $13,44 \pm 0,49^{b}$ \\
\hline Hepatopancreas & 8 & $58,37 \pm 2,86^{\mathbf{a}}$ & $18,44 \pm 1,22^{\mathrm{a}}$ \\
\hline \multirow[t]{3}{*}{ Intestine } & 8 & $44,74 \pm 1,02^{\mathrm{c}}$ & $12,02 \pm 0,46^{6}$ \\
\hline & & \multicolumn{2}{|c|}{ Protease } \\
\hline & & Activity (U/ml) & Specific Activity (U/mg) \\
\hline Mixed viscera & 8 & $3,16 \pm 0,05^{\mathbf{b}}$ & $0,80 \pm 0,01^{\mathbf{b}}$ \\
\hline Hepatopancreas & 8 & $7,30 \pm 0,07^{\mathbf{a}}$ & $2,30 \pm 0,02^{\mathbf{a}}$ \\
\hline \multirow[t]{3}{*}{ Intestine } & 10 & $1,21 \pm 0,09^{\mathrm{c}}$ & $0,37 \pm 0,03^{\mathbf{c}}$ \\
\hline & & \multicolumn{2}{|c|}{ Amylase } \\
\hline & & Activity $(\mathrm{U} / \mathrm{ml})$ & Specific Activity (U/mg) \\
\hline Mixed viscera & 8 & $27,08 \pm 0,87^{\mathbf{b}}$ & $6,89 \pm 0,22^{b}$ \\
\hline Hepatopancreas & 8 & $36,35 \pm 0,79^{\mathbf{a}}$ & $11,47 \pm 0,25^{\mathrm{a}}$ \\
\hline Intestine & 8 & $18,73 \pm 0,72^{\mathrm{c}}$ & $5,03 \pm 0,19^{\mathbf{c}}$ \\
\hline
\end{tabular}

\section{Trang 36}


Values are given as means $( \pm \mathrm{SD})$ for three individuals. Different superscript letters indicate significant differences $(\mathrm{p}<0.05)$

All lipase, protease, amylase activities were significantly higher in the hepatopancreas compared with the intestinal sections and mixed viscera $(\mathrm{p}<0.05)$. The result was similar to the work of Natalia et al. (2004), which showed the highest activity level of lipase was in the pancreas and intestine of Scleropages formormosus.

The specific lipase activity from the hepatopancreas of Tra catfish at $18.44 \pm 1.22$ $\mathrm{U} / \mathrm{mg}$ protein was higher than that from the hepatopancreas of red sea bream, $3.81 \mathrm{U} / \mathrm{mg}$ protein (N.lijima et al. 1998) but lower than that from caecal mass of Pacific bluefin tuna Thunnus orientalis, $27.5 \pm 4.6 \mathrm{U} / \mathrm{mg}$ protein (A.M. de la Parra et al. 2007).

The specific protease activity from the hepatopancreas of Tra catfish $(2.3 \pm 0.02 \mathrm{U} / \mathrm{mg}$ protein) was higher than that from the rohu $(1.219 \pm 0.059 \mathrm{U} / \mathrm{mg}$ protein/min) but lower than that from the hepatopancreas of crawfish
Procambarus Clarkii (5.2 U /mg protein) (Yoonhwa Jeong et al. 2000). This result was approximately with protease extracted from the viscera of three tuna species $(2.28-3.06 \mathrm{U} / \mathrm{mg}$ protein) (Prasertsan et al., 2008).

The specific amylase activities from the hepatopancreas of Tra catfish (11.47 \pm 0.25 $\mathrm{U} / \mathrm{mg}$ protein) was considered as quite low in comparison with those from plant sources.

\subsection{Properties of the crude enzymes from} viscera of Tra catfish

\section{Effect of pH on enzyme activities}

The effect of $\mathrm{pH}$ in the $\mathrm{pH}$ range of 6.011.0 on the activity of crude enzymes extracted from viscera of Tra catfish was investigated. (Fig.4,5,6) 


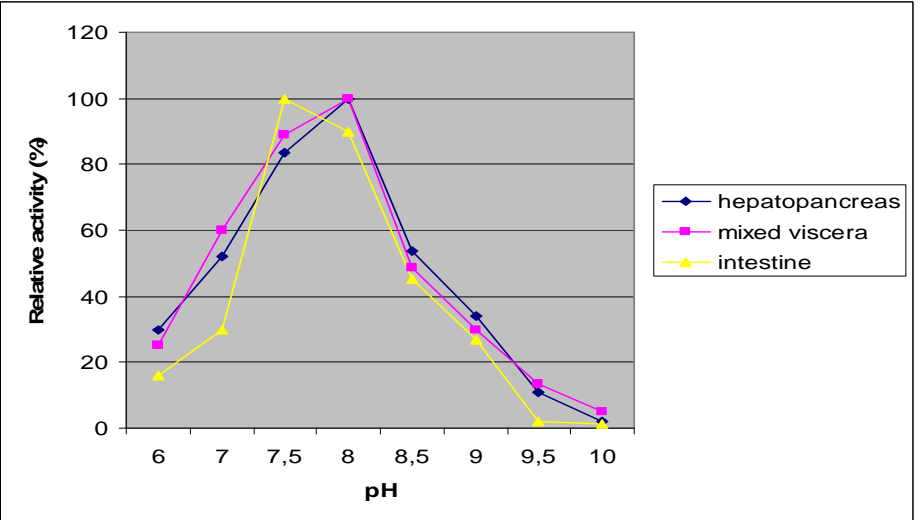

Fig 4. Effect of $\mathrm{pH}$ on lipase activity of enzymes extracted from hepatopancreas, intestine and mixed viscera

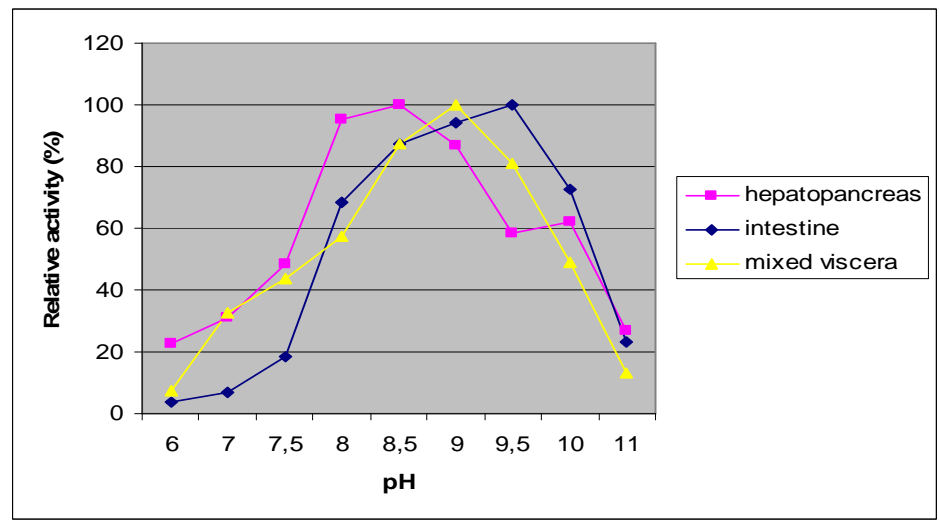

Fig 5. Effect of $\mathrm{pH}$ on protease activity of enzymes extracted from hepatopancreas, intestine and mixed viscera

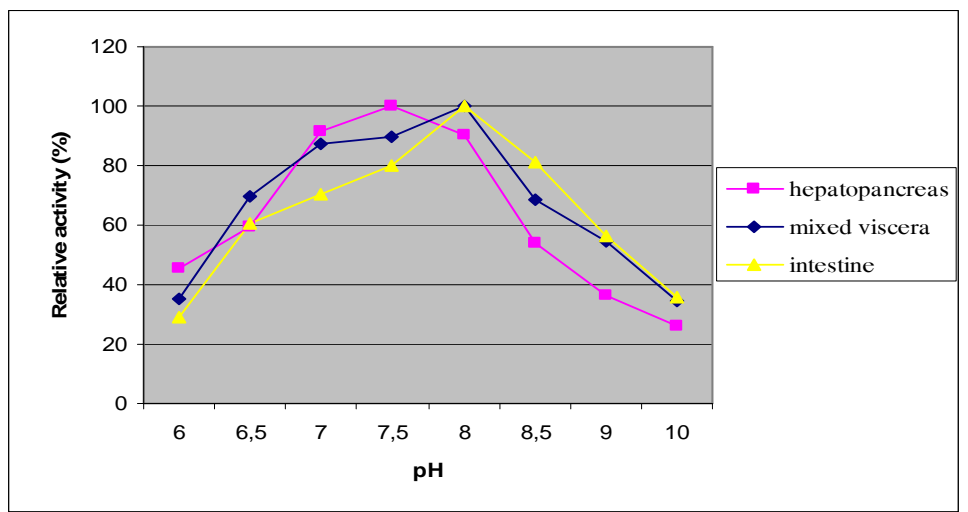

Fig 6. Effect of $\mathrm{pH}$ on amylase activity of enzymes extracted from hepatopancreas, intestine and mixed viscera

Results revealed that the lipase activity had an optimal $\mathrm{pH}$ of $8,7.5$ and 8 for the hepatopancreas, intestine and mixed viscera respectively. The optimum $\mathrm{pH}$ 7 9 for lipase activities were reported for fish and other sources (Prasertsan et al., 2001; Natalia et al., 
2004; Gjellesvik et al., 1992). M. K. Mukundan et al. (2006) reported similar results with oil sardine (Sardinella longiceps linnaeus) hepatopancreas lipase activity at an optimal $\mathrm{pH}$ of 8 . Protease activity had an optimal $\mathrm{pH}$ of 8.5, 9.5 and 9 for the hepatopancreas, intestine and mixed viscera, respectively. The results were in line with the work of Yoonhwa Jeong et al., (2000) reported proteases, trypsin-like enzymes from hepatopancreas of crawfish (Procambarus Clarkii) having optimum $\mathrm{pH}$ of 8-8.5.

Amylase activity had an optimal $\mathrm{pH}$ of 7.5 , 8 and 8 for the hepatopancreas, intestine and

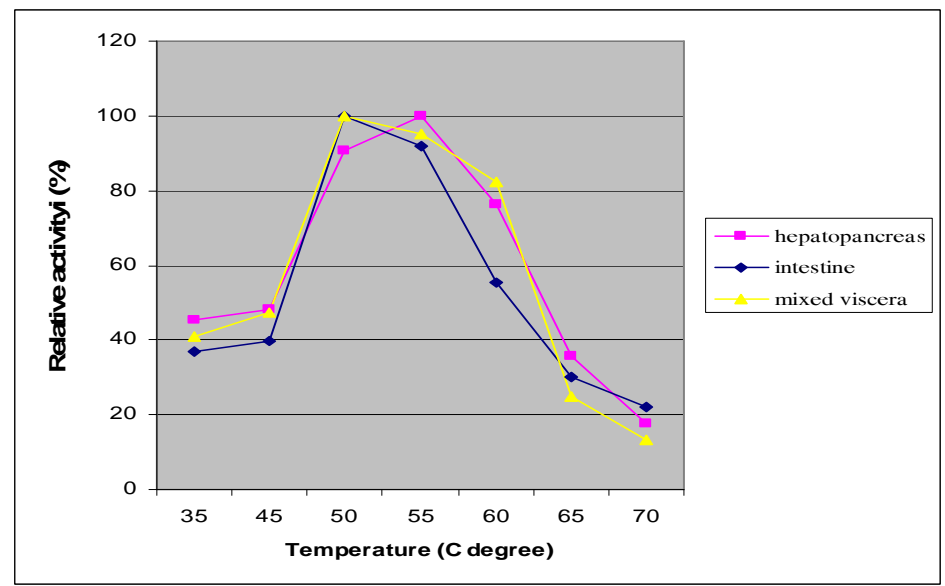

Fig 7. Effect of temperature on lipase activity of enzymes extracted from hepatopancreas, intestine and mixed viscera mixed viscera, respectively. At optimum $\mathrm{pH}$ enzymes from hepatopancreas possessed the highest lipase, protease and amylase activities of $67.26,7.5$ and $39.37 \mathrm{U} / \mathrm{ml}$ with the specific activities of $17.47 ; 2.12$ and $10,8 \mathrm{U} / \mathrm{mg}$, respectively.

\section{Effect of temperature on enzyme activities}

The influence of temperature on enzyme activity was determined at temperatures ranging between 35 and $70^{\circ} \mathrm{C}$ (Fig. 7, 8, 9) at their optimum $\mathrm{pHs}$. 


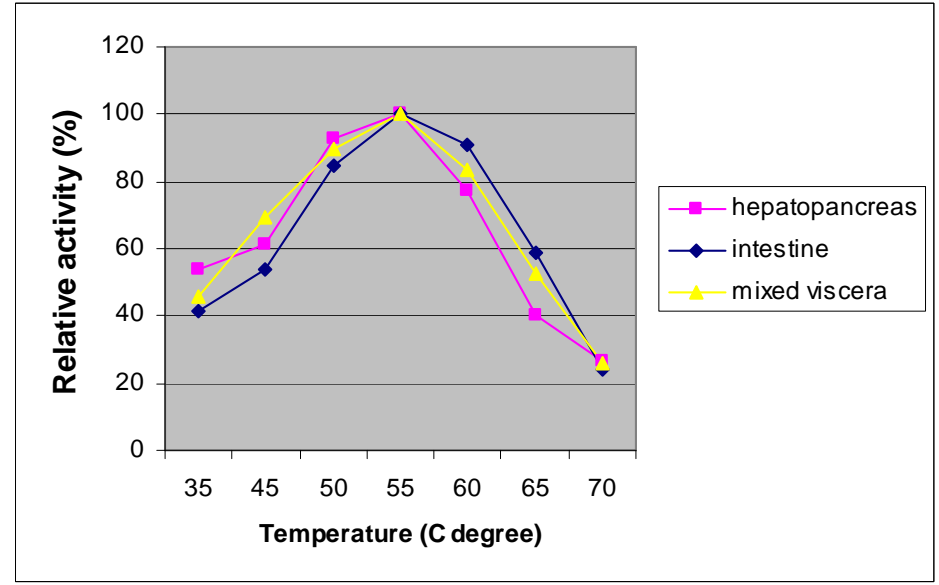

Fig 8. Effect of temperature on protease activity of enzymes extracted from hepatopancreas, intestine and mixed viscera.

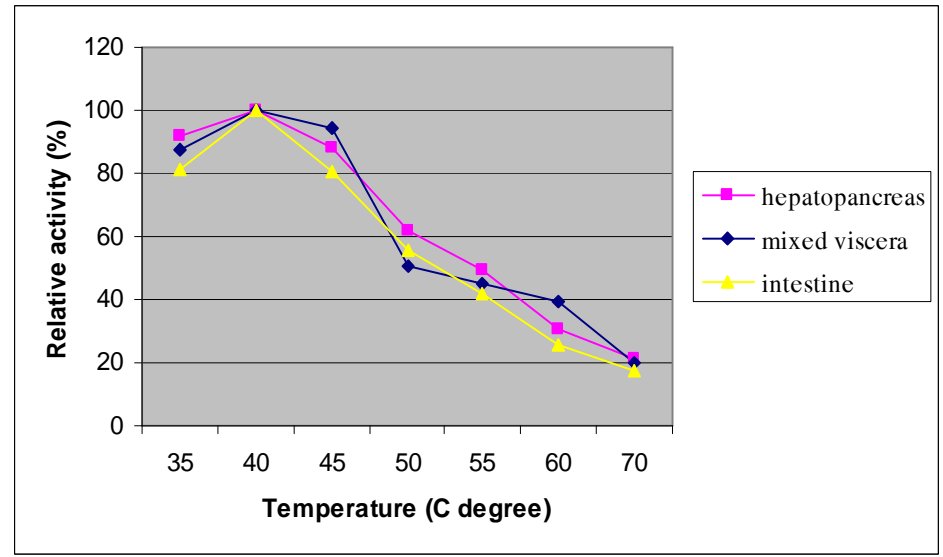

Fig 9. Effect of temperature on amylase activity of enzymes extracted from hepatopancreas, intestine and mixed viscera.

Result revealed that the maximum activities of lipase, protease, amylase for the hepatopancreas, intestine and mixed viscera were found at the temperature of 55, 55 and $40^{\circ} \mathrm{C}$, respectively. These results were similar to those reported for lipase from grey mullet $\left(55^{\circ} \mathrm{C}\right)$ (Aryee et al., 2007) which is slightly lower comparing to yellowfin tuna viscera lipase $\left(60^{\circ} \mathrm{C}\right)$ (Prasertsan et al., 1988).
The optimum temperature of proteases was lower than those of alkaline protease from four species of freshwater fish and 21 species of marine fish $\left(60-65^{\circ} \mathrm{C}\right)$ (Iwata etal., 1974).

Similar results of optimum temperature of amylase were described in tuber (Norman et al., 2006).

At optimum $\mathrm{pH}$ and temperatures, enzymes from hepatopancreas possessed the highest lipase, protease and amylase activities of 
123.26, $\quad 13.25$ and $41.07 \mathrm{U} / \mathrm{ml}$ with the specific activities of $36.08 ; 3.59$ and 10.75 $\mathrm{U} / \mathrm{mg}$, respectively. The lipase, protease and amylase activities decreased sharply at $70^{\circ} \mathrm{C}$.

\section{CONCLUSION}

The viscera of Tra catfish contain a considerable amount of protease and lipase activity that can be used in different foodprocessing aids, thereby contributing to the reduction of waste-disposal problem. Among the individual viscera organ, hepatopancreas was the best source for lipase and protease with maximal activities at $\mathrm{pH} 7.5$ and 8.5, respectively. The optimum temperature for both lipase and protease activities were $55^{\circ} \mathrm{C}$.

\title{
TÍNH CHẤT HỆ ENZYM TIÊU HÓA TRONG CÁC CƠ QUAN NỘI TẠNG CÁ TRA (PANGASIUS)
}

\author{
Vương Bảo Thy ${ }^{(1)}$, Trần Bích Lam ${ }^{(2)}$, Lưu Duẩn ${ }^{(3)}$ \\ (1) Đại học Cửu Long \\ (2) Trường Đại học Bách khoa, ĐHQG-HCM \\ (3) Trường Đại học Công nghệ Sài Gòn
}

TÓM TĂT: Trong ngành chế biến cá, nội tạng được xem là phế phẩm và thường được loại bỏ. Mục tiêu của nghiên cứu là tận dụng nội tạng cá Tra (Pangasius), chiếm 5-6\% trọng luợng co thể cá, để thu nhận các enzym tiêu hóa. Nội dung nghiên cưu tính chất của các enzym lipase, protease, amylase trong các cơ quan nội tạng khác nhau của cá Tra. Kết quả cho thấy trong ba nhóm nguyên liệu: gan tụy, ruột, nội tạng hỗn hợp thì gan tụy là nguồn nguyên liệu tốt nhất để thu nhận cả ba loại enzym tiêu hóa trên. Trong đó, hoạt tính lipase là 18.426 U.mg-1 protein, hoạt tính protease là 2.304 U.mg $^{-1}$ protein và hoạt tính amylase là 11.473 U.mg-1 protein. pH tối thích của lipase thu nhận tù gan tụy, ruột và nội tạng hỗn hợp lần luọt là 8; 7,5 và 8. pH tối thích của protease thu nhận tù gan tụy, ruột và nội tạng hỗn hợp lần luợt là 8,5; 9,5 và 9. pH tối thích của amylase thu nhận tù gan tuyy, ruột và nội tạng hốn hợp lần luợt là 7,5; 8 và 8 . Ở pH tối thích, hoạt tính lipase, protease và amylase cao nhất ở nhiệt độ 50,55 và $40^{\circ} \mathrm{C}$.

Tù khóa: enzym tiêu hóa, nọi tạng, lipase, protease, amylase.

\section{REFERENCES}

[1] Anna Lindberg, Gunilla Olivecrona, Lipoprotein lipase from rainbow trout differs in several respects from the enzyme in mammals, Gene, 213-223 (2002).

[2] Aryee, A. N. A., B. K. Simpson, R. Villalonga, Lipase fraction from the 
viscera of grey mullet (Mugil cephalus): Isolation, partial purification, and some biochemical characteristics, Enzyme Microb. Technol. 40: 394-402 (2007).

[3] Borlongan IG, Studies on the digestive lipases of milkfish Chanos chanos, Aquaculture 89: 315-325 (1990).

[4] Chesley, L. C., The validity of the viscometric and Wohlgemuth methods for the quantitative determination of amylase, Journal of Biological Chemistry, 92-171 (1931).

[5] Gjellesvik, D.R., A.J. Raae and B.T. Walther, Partial purification and characterization of a triglyceride lipase from Cod (Gadus morhua), Aquaculture 79: 177-184 (1989).

[6] Gjellesvik, D. R., D. Lombardo, and B. T. Walther, Pancreatic bile salt dependent lipase from cod (Gadus mоrhua): purification and properties, Biochim. Biophys. Acta., 1124: 123-134 (1992).

[7] Klomklao S, Benjakul S, Visessanguan W, Kishimura H,Simpson BK, Purification and characterization of trypsins from the spleen of skipjack tuna (Katsuwonus pelamis), Food Chem 100:1580-1589 (2007).

[8] Lowry O H, Rosebrough N J, Farr A L \& Randall R J., Protein measurement with the Folin phenol reagent, Journal of Biological Chemistry, 193:265 (1951).

[9] M. K. Mukundan, K. Gopakumar, M. R. Nair, Purification of a lipase from the hepatopancreas of oil sardine (Sardinella longiceps linnaeus) and its characteristics and properties, Journal of the Science of Food and Agriculture 36: 191 - 203 (2006).

[10] Munilla-Mordn, R. and F. SaboridoRey, Digestive enzymes in marine species II: Amylase activities in gut from seabream (Sparus aurata), turbot (Scophthalmus maximus), and redfish (Sebastes mentella), Comp. Biochem. Physiol. B 113: 827-834 (1996).

[11] Natalia, Y., R. Hashim, A. Ali and A. Chong, Characterization of digestive enzymes in a carnivorous ornamental fish, the Asian bony tongue Scleropages formosus (Osteoglossidae), Aquaculture 233 (1-4): 305-320 (2004).

[12] Noman, A. S. M., M. A. Hoque, P. K. Sen, and M. R. Karim, Purification and some properties of a amylase from post-harvest Pachyrhizus erosus L. tuber, Food Chem. 99: 444-449 (2006).

[13] Prasertsan, P., S. Jitbunjerdkul, Trairatananukoon, and $\mathrm{T}$. Prachumratana, Production of enzyme and protein hydrolysate from fish processing waste. 63-72, In: S. Roussos, C. R. Soccol, A. Pandey, and C. Augur (eds.), New horizons in Biotechnology, Kluwer Academic Publisher, India (2001) .

[14] Sarath G, De la Motte RS, Wagner FW, Protease assay methods, In: Beynon R, Bond J (eds), Proteolyic enzymes: a 
practical approach, IRL, Oxford, 25-56 (1989).

[15] Yoonhwa Jeong, Cheng-I Wei, James F. Preston and Maurice R. Marshall, Purification and characterization of protease from hepatopancreas of crawfish (Procambarus Clarkii), Journal of Food Biochemistry 24: 311332 (2000). 